\title{
6
}

\section{Tracing the Historical Development of a Service Model for Interagency Collaboration: Contradictions as Barriers and Potential Drivers for Change}

\section{Paulo Rocha and Sarah Hean}

\section{Introduction}

The average person entering the criminal justice system (CJS) grapples with mental health problems (Fazel \& Danesh, 2002). These disenfranchised individuals are also prone to substance misuse problems and other social difficulties such as unemployment, debt and homelessness (World Health Organisation, 2015), which increases their proclivity to offend/reoffend (Hare, 2002). To that end, effective rehabilitation strategies need to tackle clusters of correlated risk factors and provide multifaceted solutions in order to decrease reoffending rates (Andrews \& Bonta, 2016).

\section{P. Rocha ( $\square)$}

Department of Social Studies, University of Stavanger, Stavanger, Norway e-mail: paulo.t.bastosrocha@uis.no

S. Hean

Social Work Department, University of Stavanger, Stavanger, Norway e-mail: sarah.c.hean@uis.no 
By and large, rehabilitation strategies tend to be rolled out in prison by the state. However, the suboptimal conditions that exist in the prison system limit the rehabilitation efforts deployed (Farrington, 2006; Skeem $\&$ Peterson, 2012). This means the concomitant deployment of rehabilitation programmes in the community are vital. Indeed, the importance of through-of-the-gate support is well recognised in the United Kingdom and care, enabled through collaboration between criminal justice (CJS) and welfare systems (WS), is considered to be key to success (Ministry of Justice UK, 2013). However, collaboration often collapses due to incompatible agendas of the different agencies and philosophical differences among professionals (Stone, 2003).

In England and Wales, Criminal Justice Liaison and Diversion (L\&D) services work specifically with vulnerable people when they are first in contact with the criminal justice system (NHS England Liaison and Diversion Programme, 2014). These services first identify vulnerable individuals entering the criminal justice system and refer them to appropriate care. Additionally, L\&D services ensure that data about service users arrive at decision-makers in the criminal justice system (e.g. courts and police) to inform their choices (e.g. in sentencing or providing treatment) (Reed, 1992).

Initially L\&D services were managed and funded locally. This meant that not all areas nationally had L\&D services available and, among those that had, there was considerable variation in the nature of service (Disley et al., 2016). Responsive to this challenge, the government in England commissioned a study to review the conditions of people with mental health problems or learning disabilities in the criminal justice system. The findings of the review recommended there should be an expansion of L\&D services (Bradley, 2009) and this galvanised the development of a national model across England to standardise L\&D practices nationwide (NHS England Liaison and Diversion Programme, 2014).

The model posited that vulnerabilities should be identified as soon as the individuals entered the criminal justice system, which meant having L\&D workers placed in court and police stations to assist in the screening, assessment and signposting of offenders to the relevant care as required. The model also instructed L\&D workers to, if appropriate, 
divert the offender out of criminal justice altogether and into care (NHS England Liaison and Diversion Programme, 2014). The national government had a goal to reduce duplication of effort and resolve complications in collaboration between agencies. They aimed to enable criminal justice and welfare systems to work together in tandem and avoid silo working that could otherwise be pernicious to service users (Rogers \& Ormston, 2016).

Ten sites across six areas in England (North, Midlands, East, London, South East and South West) were forerunners in the trial of the new model in 2014 (Disley et al., 2016). The results demonstrated that L\&D efforts had a substantial impact on decreasing the number of arrests (Bonkiewicz et al., 2014) and increasing positive outcomes for primary health care (Earl et al., 2015). However, organisational aspects behind L\&D's influence were underexplored (Pakes \& Winstone, 2009, 2010). This book chapter addresses this shortfall by grappling with L\&D's organisational processes and work activity. The focus is on the perspective of professionals working directly with clients within both L\&D and its neighbouring services. To that end, the chapter constructs a historical perspective of $\mathrm{L} \& \mathrm{D}$ activity providing a timeline whereby tensions and potential contradictions within and between L\&D, and neighbouring services activity systems are identified before, during and after the process of implementation of the national model. The development of a historical understanding, by tracing contradictions back to their origins, is paramount if these are to be resolved and the service developed further.

\section{Cultural-Historical Activity Theory as a Means of Exploring the Implementation of the National L\&D Model}

Cultural-historical activity theory (CHAT) is a multidisciplinary model which has gained increasing popularity and relevance among researchers in the fields of education and organisation studies (see e.g. Engeström, 1987; Engeström et al., 1999; Adler, 2005; Sannino et al., 2009). It has, for example, been adopted as an analytical tool in organisational studies 
(Blackler, 1993, 2009), human resource development and management practices (Ardichvili, 2003; Fenwick, 2006; Gvaramadze, 2008), and organisational and individual learning (Engeström et al., 2007; Schulz \& Geithner, 2010). However, it has not been yet widely applied to the study of collaborative practices in offender rehabilitation settings.

CHAT is an object or goal-oriented approach that promotes the study of work activity from the standpoint of a chosen subject (a front-line worker, for example). It investigates how the subject and their collaborative community carry out a specific object/goal engrossed in an overall work activity through the mediation of artefacts, rules and division of labour (Engeström, 1987). The mediation tends to be two-directional. Initially, culturally produced artefacts and tools are internalised by the subjects engaged in the activity and this shapes their consciousness. Subsequently, the same artefacts and tools give the subject the leverage to shape the activity in which they were produced in the first place, which is a process called externalisation (Daniels, 2001). Simply put, the tool shapes the subject who in turn shapes the world through using the tool (Cole, 1996). Different agencies may be engaged in different work activities, each described in terms of a separate activity system. Nonetheless, together they represent a community of separate-but interconnectedactivity systems that may or may not share common goals/objects, as represented in Fig. 6.1.

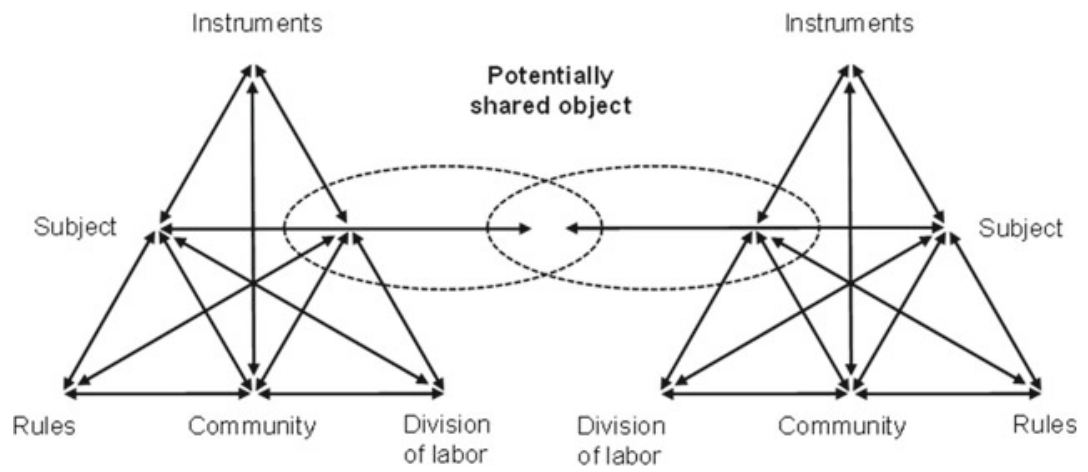

Fig. 6.1 Activity as a dynamic model of interlinked activity systems (see Engeström, 2000, p. 306) 
Activity systems develop over time and across cultures through resolution of the contradictions lurking within and/or between each of the nodes of the triangle or even between activity systems (Engeström, 1987). This premise can be traced back to Vygotsky's lessons which predicated human consciousness being determined by their activity (Daniels, 2001). In this vein, the work routines devised by professionals at the several L\&D sites are an embodiment of their consciousness, which takes place through their activities predicated on local contingencies. In the analysis of these local practices, it is critical to take into account the cultural and historical circumstances of each L\&D site in order to avoid overly simplistic models of explanation. In other words, CHAT is used as an analytical tool because its epistemological approach combines both historical and cultural dimensions of social phenomena to make sense of activities, i.e. CHAT has utility as an exploratory tool because it allows the study of collaboration at a systems level and accounts for the multiple factors that mediate collective work activity (Engeström, 1999). In the offender rehabilitation context, these systems might be two adjacent services that have separate but also some common goals: working together on the same piece of rehabilitation strategy, for example, police custody officers collaborate with $\mathrm{L} \& \mathrm{D}$ workers to screen and assess individuals for vulnerabilities (their shared object of activity) when they enter the criminal justice system.

When participants within or between activity systems encounter tensions, obstacles and challenges that stem from contradictions in their work activity, this may prevent or limit the actors from achieving their goal/object and the desired outcome (Engeström \& Sannino, 2011). Nonetheless, the historically evolved and systemic contradictions ought not to be perceived as elusive inconveniences, but rather as central "sources of change and development" (Engeström, 2001, p. 137). They have the potential to become influential factors that force the system to reconfigure through a process of 'expansive learning' (Engeström, 2001) (see Chapters 1 and 8 for a more detailed description of expansive learning). 


\section{An Activity Theoretical Case Study of Liaison and Diversion Services}

\section{Study Description}

The chosen case study L\&D site was forerunner in the implementation of the national model since its outset in 2014 ('wave one'). The L\&D team consists of four administration staff, eight Support, Time and Recovery workers, eight mental health practitioners, two team leaders and one service manager. Due to the small size of the staff, the team leaders and the service manager also function as mental health practitioners when necessary, which transforms them into front-line workers for the effects of this study. In 2017, the service assessed 2365 adults and numbers increase yearly (Williams et al., 2019).

In addition to the entire front-line staff of the L\&D service, participants from neighbouring organisations were also involved in the research. Including the perspective of professionals from other agencies such as, for example, police and community mental health teams, contributed to the depiction of the different activity systems interacting with L\&D. The aim of study reflected in this paper was to respond the over-arching question: How is interagency collaboration between L\&D and neighbouring services perceived by street-level L\&D workers after the introduction of a new national model for Liaison \& Diversion?

The paper dwells specifically on the historical dimension of the L\&D services and provides a perspective of $L \& D$ practice both prior, during and after the implementation of the new national model. A qualitative case study approach (Yin, 2009) was used to explore collaborative practice carried out by the front-line staff of an L\&D site located in England. The case study reported here is part of a wider project that aims to improve collaboration between agencies in the criminal justice system and welfare services (Horizon 2020 funded CO-LAB MSCA-RISE project number 734536). The first phase of the study collected background information on the L\&D through document analysis, followed by second phase of observations and interviews with 
professionals from both L\&D, criminal justice and welfare systems. Data collection took place between 2017 and 2019. Table 6.1 summarises these data collection points.

Table 6.1 Data collection procedure summary

\begin{tabular}{|c|c|c|}
\hline Data & Sources & Procedure \\
\hline $\begin{array}{l}\text { Background document } \\
\text { analysis }\end{array}$ & $\begin{array}{l}\text { Materials were available } \\
\text { at the investigated } \\
\text { L\&D scheme, which } \\
\text { provided an overview } \\
\text { of the transition } \\
\text { period the scheme } \\
\text { went through } \\
\text { between being a } \\
\text { locally managed } \\
\text { organisation to being } \\
\text { a 'wave-one' site } \\
\text { following the new } \\
\text { L\&D model. The } \\
\text { dataset included } \\
\text { internal documents } \\
\text { describing the process } \\
\text { of implementation of } \\
\text { the L\&D national } \\
\text { model ( } n=27) \text { and } \\
\text { statistical reports on } \\
\text { the number of clients } \\
\text { being screened and } \\
\text { assessed in custody } \\
\text { and court upon the } \\
\text { rollout ( } n=12)\end{array}$ & $\begin{array}{l}\text { Read all the materials } \\
\text { and documented any } \\
\text { descriptive statistics } \\
\text { related to the impact } \\
\text { the new L\&D model } \\
\text { had on the } \\
\text { performance/work } \\
\text { routine of the } \\
\text { investigated scheme }\end{array}$ \\
\hline $\begin{array}{l}\text { Semi-structured } \\
\text { interviews }\end{array}$ & $\begin{array}{l}\text { Front-line workers at } \\
\text { both the criminal } \\
\text { justice system }(n=2) \text {, } \\
\text { the welfare services }(n \\
=7) \text { and the L\&D }(n= \\
19)\end{array}$ & $\begin{array}{l}\text { Audio recorded } \\
\text { semi-structured } \\
\text { Interviews, transcribed } \\
\text { and thematically } \\
\text { analysed }\end{array}$ \\
\hline Observations & $\begin{array}{l}\text { Observed participants' } \\
\text { interactions with other } \\
\text { services and the tools } \\
\text { available to facilitate } \\
\text { communication within } \\
\text { and between agencies }\end{array}$ & $\begin{array}{l}\text { Detailed field notes of } \\
\text { observations }\end{array}$ \\
\hline
\end{tabular}




\section{Sample}

Interview participants were divided into two groups. A first group included the entire L\&D front-line staff and the second group included front-line workers from other services in both the criminal justice (the Police) and welfare systems (a Community Mental Health Team, an Assertive Outreach Team, a Homeless Health Service unity and a mental health/peer support service). To be considered a front-line worker, they had to fall within the following categories (a) being a worker who interacts directly with the public he/she serves, and (b) not having work pertaining only to administrative tasks.

Out of the 28 participants, 11 were male and 17 female. All of them were British, but two of them had an immigrant background. The vast majority had a university degree in health-related field or were in the process of obtaining one. Their work experience varied greatly. While the majority had several years or even decades of experience (although not necessarily working at the same organisation), there were a few ( $n=$ 3) who were just starting their professional lives with no more one year of experience.

\section{Analysis}

A template analysis was applied to data, and a coding 'template' developed to capture themes emerging from the data set and organise them in a meaningful and useful manner (King, 2012). The analysis engendered a final template consisting of one meta-theme, one theme, three subthemes, four categories and three sub-categories, which was applied to the entire dataset and served as the basis for interpretation of the data and writing up of the findings. We used activity theory (Engeström, 1987; Engeström \& Sannino, 2011) to interpret these themes, the activity systems and the contradictions these uncovered as these emerged historically. The method allowed for open coding at the outset of the analytical process, which enabled an unconstrained exploration of various aspects of the data. However, the method also suggests the production of an a priori template to guide later stages of the analytical process. At this 
point, CHAT's principles were paramount in the attempt to reconcile open codes with structured templates. This paper draws upon findings of one of the three subthemes namely "Contradictions between the national model's instructions and working conditions at the street-level". Hereinafter, we present and discuss the findings of how L\&D front-line workers have dealt with the instructions of the new national model and how (if) they have been implemented in practice.

\section{Results of the Case Study: Historical Phases of the L\&D Work Activity}

Front-line professionals, in examining the work activity of the L\&D service, described three historical dimensions/phases: (a) before the rollout of the L\&D national model, (b) during the rollout of the L\&D national model, and (c) after the rollout of the L\&D national model. As the case study L\&D site started its operation in their current working model in 2008, data on the historical phases are presented from that point on. We used both document analysis and interviewees' accounts to trace a historical arch or trajectory of the service's development (Table 6.2).

The timeline illustrates the documents collected on the working model of the L\&D service between 2008 and 2019. These were all public documents mostly issued by the government, associated organisations or research institutions. Interviews and observations began in mid-2017, although interviews were retrospective, referring both to current and previous ways in which $\mathrm{L} \& \mathrm{D}$ had functioned and developed.

\section{The First Phase: The L\&D Service Prior to the Rollout of a New National Model}

A review of service documentation before the rollout of the national model (Table 6.2 documents between 2008 and 2014) showed that L\&D services across the country up to 2014 were funded and managed locally with wide variation in resourcing and methods of delivery in the 
Table 6.2 Timeline of data collected

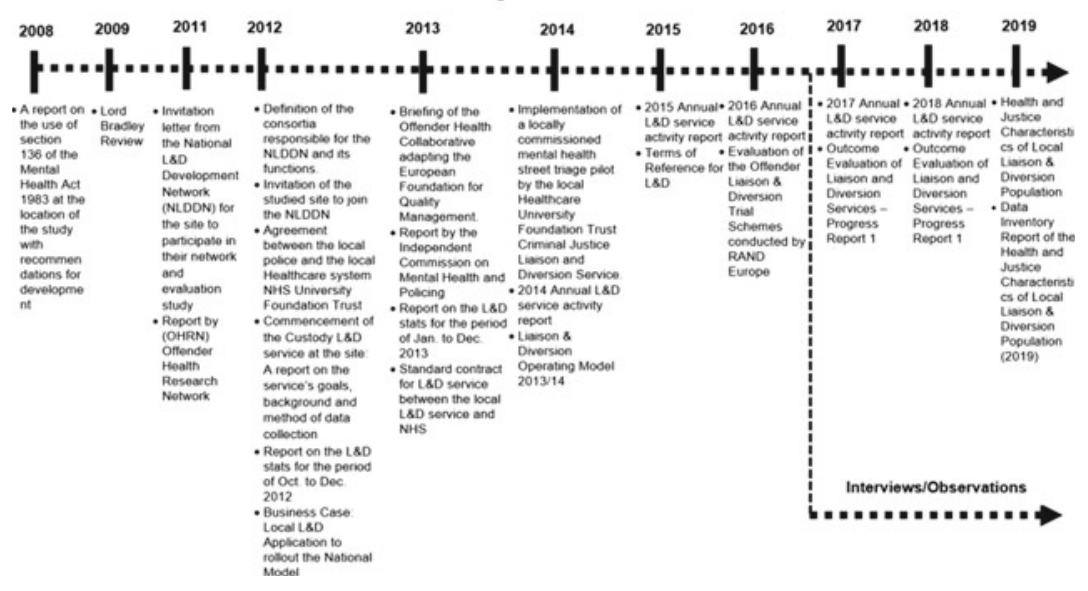

individual L\&D services. The rules and tools governing the activity of each of the L $\& D$ services were tailored for local circumstances. While one location would be staffed with mental health practitioners and support workers, others would have only health practitioners. Some locations would operate seven days a week, others would operate only from Monday to Friday. The variation in rules and available tools led to varied outcomes for the different L\&D sites. Figure 6.2 represents the contradictions existent within this phase of the L\&D activity.

There were two main tensions (see Fig. 6.2) during the work activity of the L\&D at this time, as follows:

(a) There was a tension between tools of the individual activity systems of each local L\&D service as a consequence of local rules catering to particular circumstances. Each L\&D site would operate with tools specific to their local context (e.g. local computer systems were not shared by other L\&D schemes and work routines were specific to a given context). Each site operated with different staff composition, working hours did not match, databases were not shared and communication tools varied. In light of the compartmentalised 


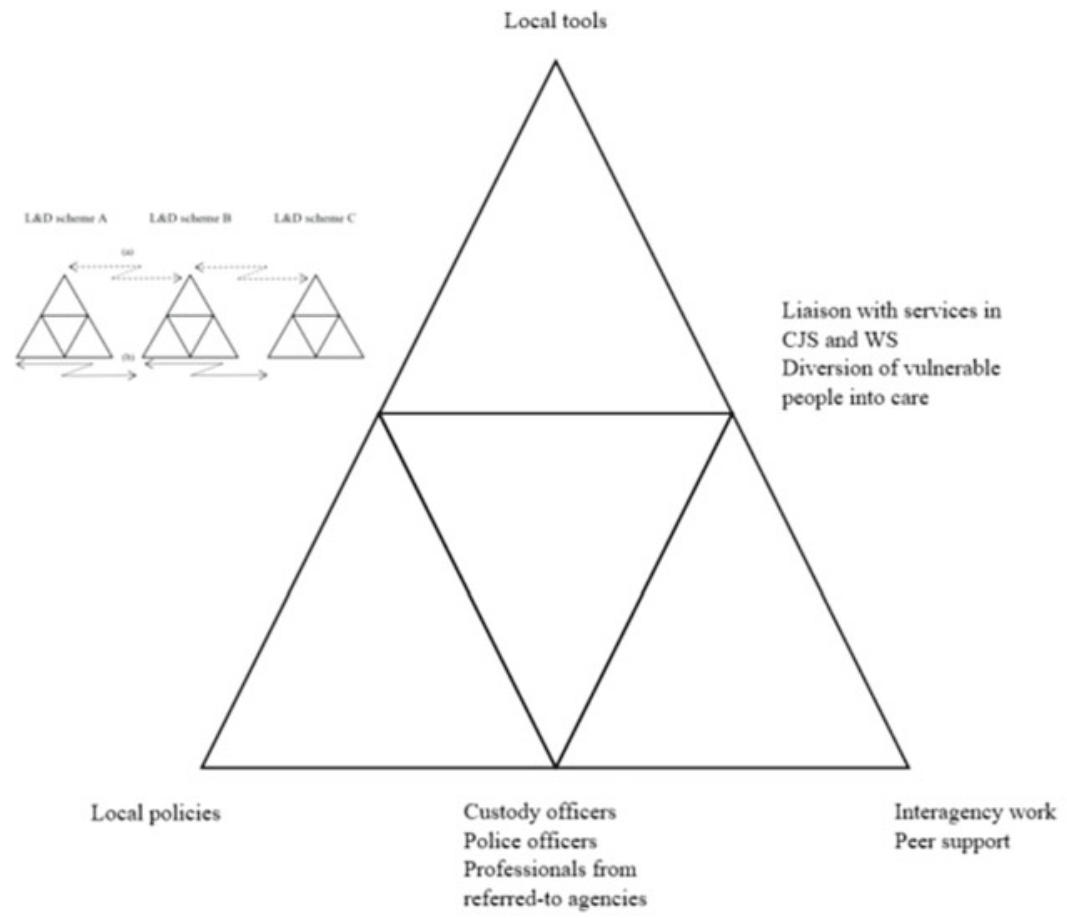

Tensions

(a) Contradictions between divergent tools (each L\&D scheme would use different collaboration tools)

(b) Contradictions between rules (each region would produce its own regulation)

Fig. 6.2 The first phase-before the rollout of the L\&D national model and the contradictions within the element 'subject' of the L\&D activity system

characteristics of the service back then, these tools were not interconnected between sites and any attempt to collaborate between L\&D services was troublesome. These conditions forced sites into isolation, information from one L\&D site not being shared with others, and a comparison of outcomes across sites being impossible.

(b) There was also a tension between the rules of the individual activity systems of each local L\&D service. Rules were devised by and for local L\&D services, which meant a high degree of variation between 
sites. In this sense, having organisations operate under the L\&D's umbrella was not a guarantee of similar practices being implemented: local contingencies had a strong impact on the rules governing the service.

These tensions identified were repeatedly mentioned by interviewees and substantiated by the analysis of documents between 2008 and 2014, more specifically documents such as the Bradley review (2009), the Report by the Offender Health Research Network (2011) and the Report by the Independent Commission on Mental Health and Policing (2013), which reported on the discrepancy between work routines at different L\&D sites.

L\&D services deal typically with vulnerable people who have no fixed residence, no permanent job and a chaotic lifestyle. They may move around the country and come into contact with criminal justice services in different areas. Information sharing between L\&D sites is key if the service is to avoid unnecessary repetition and overlap in treatment. In this sense, the tensions illustrated in Fig. 6.2, pre roll out of the national model, were an impediment to optimal service performance. The difficult communication between L\&D sites limited information sharing and each location ended up treating service users as if it was their first contact with the service. That was a resource-consuming practice. Despite a need for collaboration across sites because of clients' mobility, there was minimal support for local L\&D services trying to collaborate and this forced them to operate in isolation. Moreover, any attempt to compare outcomes between locations failed because of the diverse peculiarities of each region.

In an attempt to transcend these tensions, the government in England and Wales intervened. Their aim was to ensure that vulnerable people who were in contact with the criminal justice system would be endowed with homogeneous and commensurate support. This lead to the commissioning of the Lord Bradley Review (Bradley, 2009) and the development of a national L\&D model to standardise the rules, tools and objectives applied to L\&D services across the country as well as to expand the number of locations in which $L \& D$ services were available. 


\section{The Second Phase: The L\&D Services During the Rollout of a New National Model}

Our document analysis-more precisely, documents such as the Invitation Letter from the National Liaison and Diversion Development Network (2011)—pointed out that in 2011, the Department of Health in England invited 54 liaison and diversion sites across the country to join a newly created network that would inform Lord Bradley's Review (Bradley, 2009) and advocate for the development of the L\&D national model focused on standardising practice across the country and ensuring equal conditions at all locations (Department of Health, 2011).

The national model was largely developed based on the evidence produced by the aforementioned Bradley review and aimed to clarify and standardise several points that were previously managed locally (NHS England Liaison and Diversion Programme, 2014). The model recommended, for example, the provision of support workers as part of the L\&D service (NHS England Liaison and Diversion Programme, 2014, p. 24), the need for partnership with services in criminal justice and welfare systems (by placing L\&D workers in police stations and courts) (NHS England Liaison and Diversion Programme, 2014, p. 21), and 24/7 coverage for L\&D services (NHS England Liaison and Diversion Programme, 2014, p. 5). Furthermore, the model proposed that all the L\&D sites across the country should pursue the same goals, namely: improved access to healthcare and support services for vulnerable individuals; diversion of individuals, where suitable; the delivery of efficiencies; and an overall reduction of reoffending (NHS England Liaison and Diversion Programme, 2014, p. 10).

The national model for $L \& D$ services represents the outcome of the expansive learning engaged in by policymakers and service developers in response to the tensions that local services had been experiencing historically. The response was a new or expanded L\&D activity system (Fig. 6.3). With the new national policy in place, local L\&D sites were then expected to transition from their locally-based management approach to a new one that incorporated the standard instructions of the national model. Here, however, new tensions arose. As reported by 


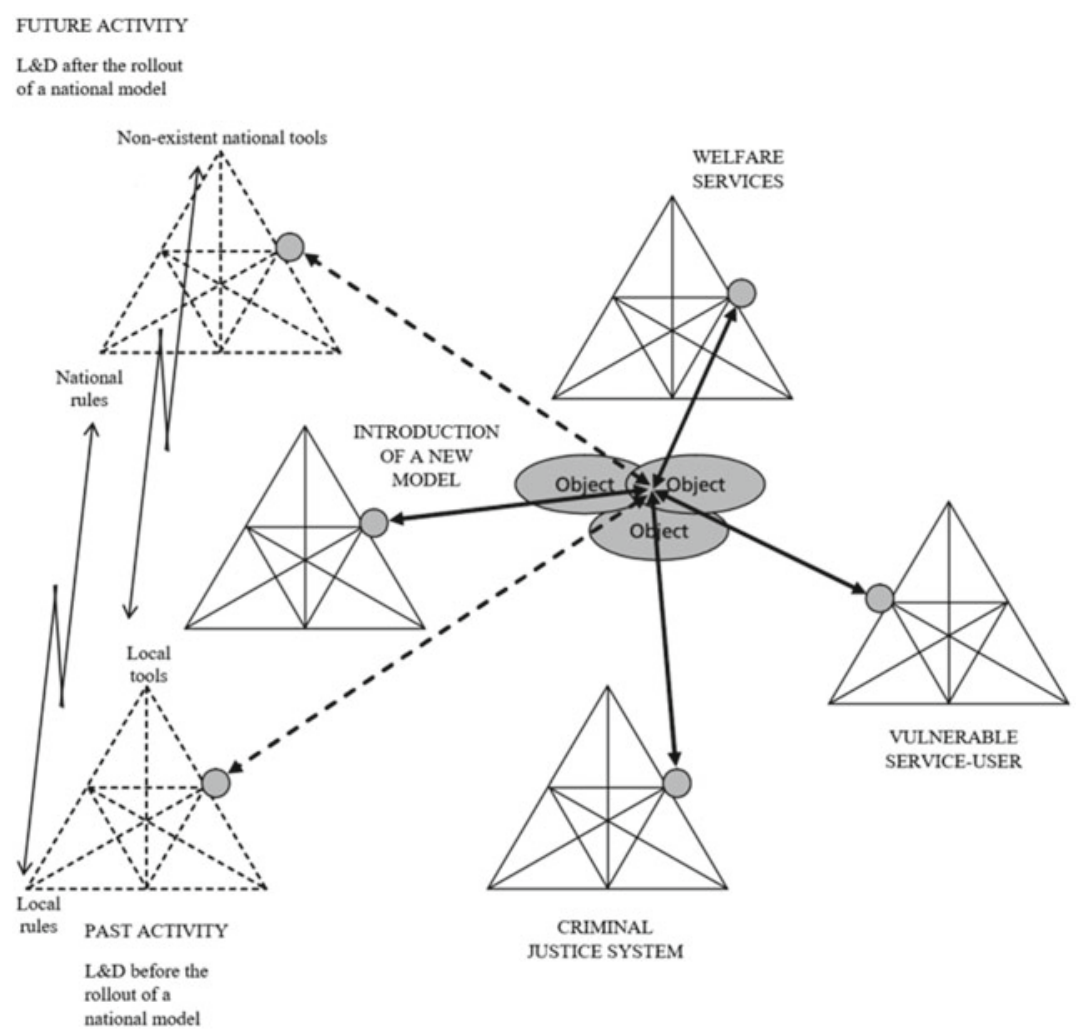

Fig. 6.3 The Second Phase-during the rollout of the L\&D national model. A contradiction between an old and a new improved L\&D activity system

participants, the national model did not take into account local contingencies and applying the national standardised model uniformly across various $\mathrm{L} \& \mathrm{D}$ sites proved impossible.

In this scenario, tensions between the local $L \& D$ services (each one representing an independent activity system governed by local rules in the historical pre-national model) and the new standard policy (where all L\&D sites would have to follow the instructions of the national model) started to occur. This historically evolved contradiction stems from tensions that happened between an old and a new activity system after 
an intervention, or organisational change has taken place (Engeström, 1987).

The contradiction illustrated in Fig. 6.3 developed because the new model, while unifying the rules being applied across sites, did not take into account the presence of local tools and operational aspects of the L\&D service. Nevertheless, a review of the 'wave one' sites (Disley et al., 2016) demonstrated that the new national model had had a positive impact on service outcomes (e.g. an increase in the number of vulnerable cases identified in custody, an increase in the number of referrals to welfare services, improved access to information by court professionals). The caveat is that the review did not look into the organisational stability of the various $L \& D$ sites and the context under which they operated, which was the focus of our study. In the end, reviewing L\&D through an activity theoretical lens showed that although the new model introduced new rules and championed standardised outcomes, it did not provide L\&D services with new tools to promote liaison with other agencies. In this sense, we were not able to produce evidence that dovetails with the positive impact on service outcomes reported (Disley et al., 2016) and the introduction of the new model.

\section{The Third Phase: The L\&D Service After the Rollout of a New National Model}

Figure 6.4 represents the $L \& D$ activity systems after the rollout of the national model (current practice). The national model (Rule) has now begun to influence the way the service is funded and has managed to introduce standardised outcomes (NHS England Liaison and Diversion Programme, 2014) against which sites have their performance equally judged (indeed an expansion of the original L\&D activity systems). Diverse locations are still operating using old tools, however, to apply these new rules of the national model to their local circumstances.

Interviewees who had participated in the implementation of the new model, and who are still working for L\&D described other tensions during this phase. Now, contradictions seem to occur not only between L\&D sites but also between the L\&D and other criminal justice and 

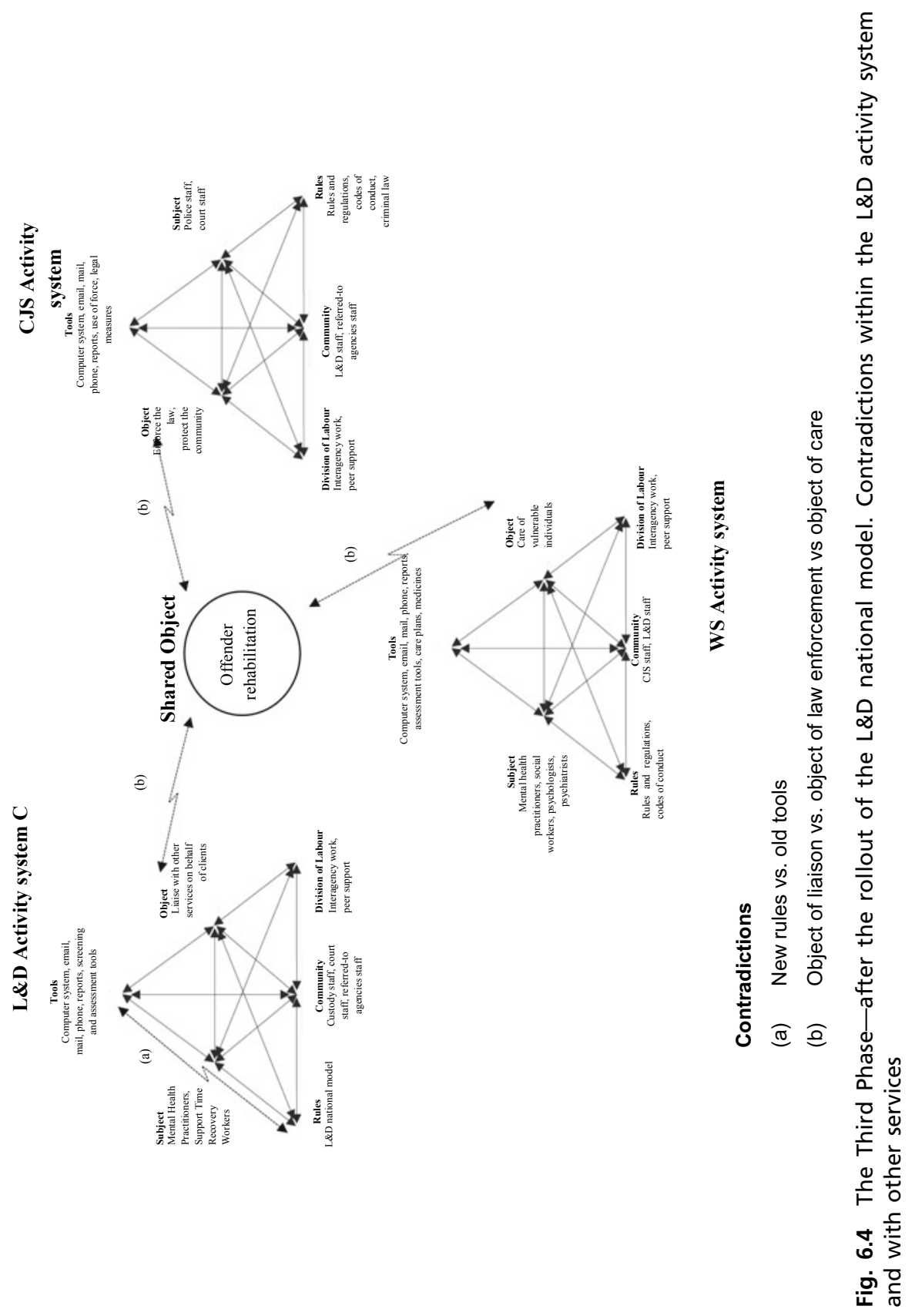
welfare services. That is to say that the national model was not able to significantly transform interagency collaborative practice as had been expected. Professionals from the L\&D, the criminal justice and welfare systems work together in an interdisciplinary network surrounding vulnerable service-users. Interviewees mentioned how IT systems are the default communication tool between professionals, but reported that technology-related activities are still confined within the boundaries of each organisation. In these conditions, they described information sharing to support communication between services as insufficient. These tensions might have been already present prior to the new model but are particularly salient in the current climate. There were exceptions, however, to this compartmentalisation of IT systems. For example, services funded by the National Health Service (L\&D, community mental health teams, assertive outreach teams) used the same software and were, therefore, able to exchange information through it. Nevertheless, even in such cases, the interconnection between agencies was geographically limited, as intercommunication was bound to the limits of each county.

When asked whether having access to other organisation's system would facilitate their work, professionals explained that such a solution would still have tensions associated with it, as it would require professionals across organisations to share the same skillset in order to fathom the information on each other's systems. An example was that L\&D while operating in custody had access to the police's IT system, but the police did not have access to L\&D's IT system at all. As it was clarified by participants, access was offered to the police, but the organisation declined as they felt police officers would not be able to understand the information on the system.

Participants also mentioned a conundrum amid organisations as to each other's roles, responsibilities and level of influence. While on the one hand, welfare organisations assumed it was in the police capacity and influence to deal with vulnerable people, on the other hand, the police assumed the same about welfare services. An example of such situation was given by an interviewee who explained that some welfare organisations assumed the police performed welfare checks when in fact that was a task of another crisis team in a welfare service providing assistance to 
individuals having a mental health crisis in the community. In the interviewee's opinion, this assumption may lead to individuals falling through the service net. That was not an isolated account. Overall, participants agreed that allocation of responsibilities by organisation was not clear. They acknowledged a need for more clarity about care pathways and saw the L\&D as having the task of bridging criminal justice and welfare services.

In summary, front-line professionals, when asked to speculate on the historical development of the system, highlighted that despite the introduction of the national model in an attempt to standardise L\&D provision, different locations still operate through old communication tools that vary from site to site and tensions between L\&D services remain. This tension between a new rule (the national model) being implemented and the use of old tools of communication (fragmented IT systems) reverberates out into the interactions between the activity systems of $L \& D$ and its neighbouring services in criminal justice and welfare systems. This contradiction between the activity systems of different agencies impacts on their collaborative relationships and hinders the construction of the shared object (the support and rehabilitation of the vulnerable client).

\section{Discussion and Conclusions}

The results of this study traced the development of the L\&D activity system over time. First, L\&D sites were locally managed and there was a great deal of performance variation between them. Then, during the implementation of a national model for $\mathrm{L} \& \mathrm{D}$, the government focused on replacing heterogeneity with homogeneous practice across the country. However, it tried to do so by overlooking local communication tools and strategies. The result was that local L\&D services were operationalising the new model through old tools and continued to adapt the policy to their local circumstances. This has meant that the implementation of the national model has not galvanised improved collaboration between $L \& D$ sites, and between $L \& D$ and neighbouring services in criminal justice and welfare systems, as envisaged. 
The L\&D case exemplifies a top-down attempt to address an existent shortcoming in the service, namely the lack of communication across $L \& D$ sites that led to heterogeneous practice. In CHAT, this sort of contradiction cannot be resolved through a forceful adaptation of practice to a unilaterally developed solution. Contradictions do trigger an expansive learning process in which stakeholders begin to question current routines, leading eventually to a resolution. But this requires a coreconceptualisation of practice by all those involved (Kajamaa \& Schulz, 2018). Routines are the reification of ready-made solutions to recurring problems and their persistence keeps organisational evolution at bay. Therefore, it is paramount to square routines and innovative initiatives.

As we could observe in our study, the process of implementation of the new national model policy resulted in the occurrence of new contradictions, which lay between the actors as well as between the new rule being introduced and its intended use in practice. Herein, we suggest that the stratified hierarchy of interest comprising decisionmakers and policymakers at the top, followed by middle-level managers and finally front-line professionals at the bottom might have been part of the reason for a subpar roll out of the national model for L\&D services. Under a Coalition government prevailing in the UK from 2010 to 2015, policymakers prioritised top-down performance-based commissioning in different areas of government, including welfare-towork programmes, public health budgets and criminal justice system (Bochel \& Powell, 2016). Middle-level managers strived to reconcile the new political agenda with the contingencies existent at lower levels of the government. Front-line workers felt downtrodden, as they were expected to square novel expectations introduced top-down on the one hand with sparse resources on the other.

The diversity of motives amid the different strata of the service created challenges for the implementation of the L\&D new model (an abstract concept) into concrete practice. As pointed out by Kajamaa and Schulz (2018, p. 3), "the consequences of implementation processes, however, cannot always be predicted and the efforts may lead to undesired adaptations and unanticipated outcomes", which was what we could observe in our study. Different L\&D sites adapted the national model to their own local circumstances and the national government's attempt to innovate 
did not pan out as expected at the street-level, which was most likely not accounted for at the moment of the enactment of the new policy.

The literature has already highlighted the importance of front-line workers in street-level policy implementation (Lipsky, 1980). They are crucial in the generation, coercive adoption, and bottom-up adaptation of process and social innovations (Volberda et al., 2014). Nevertheless, in the public administration, there is a proclivity to carry out innovation as a top-down process and front-line workers are in a weak position of being mere legitimisers (Elkjaer, 2002). We see dialectics between the actors of an activity system as crucial to the negotiation, design and reconceptualisation of an activity, which tends to result in a more efficient implementation process and appropriate innovation in their local context. Our study views the adaptation of the new $L \& D$ model to local contexts as an innovation process. However, this innovation process in which $\mathrm{L} \& \mathrm{D}$ services are currently engaged seems to lack a consistent and rigorous approach. It would benefit from a dialogue between all stakeholders and one that flattens out the current stratified hierarchical structure. To that end, we see opportunity for some sort of intervention that facilitates communication between these strata: between policymakers, management and front-line professionals for a description of some of these interventions, e.g., Change Laboratory Model (see e.g. Kerosuo \& Engeström, 2003; Tolviainen, 2007).

In the end, the historical development of the L\&D service described in this study originated from an identified problem of service isolation and lack of standardisation and information sharing between agencies (Bradley, 2009). It represents an expansive learning cycle that has been ongoing over the past few decades, in which contradictions within the L\&D system and also between $L \& D$, criminal justice and welfare services activity systems have triggered new ways of functioning being constructed to resolve these challenges (Engeström, 1987). The introduction of the national L\&D model as a solution being implemented and experimented with in practice (see Chapter 8 for a wider discussion of the expansive learning cycle and innovation) represented the first iteration of these learning cycles. However, not all relevant stakeholders (especially the front-line worker) were included in the learning process 
and the reconceptualisation of the L\&D model. Evidence suggests that future iterations of a more inclusive expansive learning cycle are required.

\section{References}

Adler, P. (2005). The evolving object of software development. Organization, 12(3), 401-435.

Andrews, D., \& Bonta, J. (2016). The psychology of criminal conduct. Routledge. Ardichvili, A. (2003). Constructing socially situated learning experiences in human resource development: An activity theory perspective. Human Resource Development International, 6(5), 310-325.

Blackler, F. (1993). Knowledge and the theory of organizations: Organizations as activity systems and the reframing of management. Journal of Management Studies, 30(6), 863-884.

Blackler, F. (2009). Cultural-historical activity theory and organization studies. In A. Sannino, H. Daniels, \& K. Gutierrez (Eds.), Learning and expanding with activity theory (pp. 19-39). New York: Cambridge University Press.

Bochel, H., \& Powell, M. (2016). Tre transformation of the welfare state? The Conservative-Liberal Democrat coalition government and social policy. In H. Bochel \& M. Powell (Eds.), The coalition government and social policy: Restructuring the welfare state (pp. 1-25). Bristol: Policy Press.

Bonkiewicz, L., Green, A., Moyer, K., \& Wright, J. (2014). Left alone when the cops go home: Evaluating a post-mental health crisis assistance program. Policing: An International Journal of Police Strategies \& Management, 37(4), 762-778.

Bradley, L. (2009). The Bradley report. Department of Health. http://www.dh. gov.uk/prod_consum_dh/groups/dh_digitalassets/documents/digitalasset/ dh_098698.pdf.

Cole, M. (1996). Cultural psychology. Cambridge, MA: The Belknap Press of Harvard University Press.

Daniels, H. (2001). Vygotsky and pedagogy. London: Routledge.

Department of Health. (2011). National liaison and diversion programmeDevelopment network and evaluation study. London.

Disley, E., et al. (2016). Evaluation of the offender liaison and diversion trial schemes. Cambridge: RAND. 
Earl, F., Cocksedge, K., Rheeder, B., Morgan, J., \& Palmer, J. (2015). Neighbourhood outreach: A novel approach to liaison and diversion. The Journal of Forensic Psychiatry \& Psychology, 26(5), 573-585.

Elkjaer, B. (2002). The learning organization: An undelivered promise. Management Learning, 32(4), 437-452.

Engeström, Y. (1987). Learning by expanding: An activity-theoretical approach to developmental research. Helsinki: Orienta-Konsultit.

Engeström, Y. (1999). Activity theory and individual and social transformation. In Y. Engeström, R. Miettinen, \& R. Punamaki (Eds.), Perspectives on activity theory. Cambridge: Cambridge University Press.

Engeström, Y. (2000). A story of four umpires. Organization, 7(2), 301-310. Engeström, Y. (2001). Expansive learning at work: Toward an activity theoretical reconceptualization. Journal of Education and Work, 14(1), 133-156.

Engeström, Y., \& Sannino, A. (2011). Discursive manifestations of contradictions in organizational change efforts. Journal of Organizational Change Management, 24(3), 368-387.

Engeström, Y., Kerosuo, H., \& Kajamaa, A. (2007). Beyond Discontinuity Expansive Organizational Learning Remembered. Management Learning, 38(3), 319-336.

Engeström, Y., Miettinen, R., \& Punamäki, R. (1999). Perspectives on activity theory. Cambridge: Cambridge University Press.

Farrington, D. P. (2006). Reducing crime. In A. Perry, C. McDougall, \& D. P. Farrington (Eds.), Reducing crime: The effectiveness of criminal justice interventions (pp. 1-11). West Sussex: Wiley.

Fazel, S., \& Danesh, J. (2002). Serious mental disorder in 23000 prisoners: A systematic review of 62 surveys. The lancet, 359(9306), 545-550.

Fenwick, T. (2006). Toward enriched conceptions of work learning: Participation expansion, and translation among individuals with/in activity. Human Resource Development Review, 5(3), 285-302.

Gvaramadze, I. (2008). Human resource development practice: The paradox of empowerment and individualization. Human Resource Development International, 11(5), 465-477.

Hare, R. (2002). Psichopathy and risk for recidivism and violence. In N. Gray, J. Laing, \& L. Moaks (Eds.), Criminal justice, mental health and politics of risk. London: Cavendish.

Independent Commission on Mental Health and Policing. (2013). The independent commission on mental health and policing report. Available https:// www.basw.co.uk/system/files/resources/basw_22916-3_0.pdf. Accessed 1 Aug 2020. 
Kajamaa, A., \& Schulz, K. (2018). From the abstract to the concrete-Implementation of an innovative tool in home care. Health Services Management Research, 31(1), 2-10.

Kerosuo, H., \& Engeström, Y. (2003). Boundary crossing and learning in creation of new work practice. Journal of Workplace Learning, 15, 345-351.

King, N. (2012). Doing template analysis. In G. Symon \& C. Cassell (Eds.), Qualitative organizational research: Core methods and current challenges (pp. 426-450). London: Sage.

Lipsky, M. (1980). Street-level bureaucracy: Dilemmas of the individual in public services. New York: Russell Sage.

Ministry of Justice UK. (2013). Transforming rehabilitation: A revolution in the way we manage offenders. London: The Stationery Office.

NHS England Liaison and Diversion Programme. (2014). Liaison and diversion operation model 2013/14. London: The NHS Constitution.

Offender Health Research Network. (2011). Liaison and diversion services: Current practices and future directions.

Pakes, F., \& Winstone, J. (2010). A site visit survey of 101 mental health liaison and diversion schemes in England. The Journal of Forensic Psychiatry \& Psychology, 21(6), 873-886.

Pakes, F., \& Winstone, J. (2009). Effective practice in mental health diversion and liaison. The Howard Journal of Criminal Justice, 48(2), 158-171.

Reed, J. (1992). Review of health and social services for mentally disordered offenders and those requiring similar services. In Department of Health/Home Office. London: HMSO.

Rogers, L., \& Ormston, G. (2016). Successful strategies for working with mentally disordered offenders within a complex multi-agency environment. In J. Winstone (Ed.), Mental health, crime and criminal justice: Responses and reforms (pp. 218-241). London: Palgrave Macmillan.

Sannino, A., Daniels, H., \& Gutierrez, K. (2009). Activity theory between historical engagement and future-making practice. In A. Sannino, H. Daniels, \& K. Gutierrez (Eds.), Learning and expanding with activity theory (pp. 1-18). New York: Cambridge University Press.

Schulz, K., \& Geithner, S. (2010). Individual and organizational development as interplay: An activity oriented approach. German Journal of Research in Human Resource Management, 24(2), 130-151.

Skeem, J. L., \& Peterson, J. K. (2012). Identifying, treating, and reducing risk for offenders with mental illness. In J. Petersilia \& K. Reitz (Eds.), The Oxford handbook of sentencing and corrections. Oxford: Oxford Handbooks Online. 
Stone, N. (2003). A companion guide to mentally disordered offenders. Crayford: Shaw and Sons.

Tolviainen, H. (2007). Interorganisational leaning across levels: An object orientate approach. Journal of Workplace Learning, 19(6), 343-358.

Volberda, H., Van Den Bosch, F., \& Mihalache, O. (2014). Advancing management innovation: Synthesizing processes, levels of analysis and change agents. Organization Studies, 35(9), 1245-1264.

Williams, N., Sadler, S., Durcan, G., \& Mayers, A. (2019). Health and justice characteristics of Dorset's liaison and diversion population. Unpublished manuscript.

World Health Organisation. (2015). Global strategy on people-centred and integrated health services. Geneva: WHO.

Yin, R. (2009). Case study research and applications: Design and methods. London: Sage.

Open Access This chapter is licensed under the terms of the Creative Commons Attribution 4.0 International License (http://creativecommons.org/ licenses/by/4.0/), which permits use, sharing, adaptation, distribution and reproduction in any medium or format, as long as you give appropriate credit to the original author(s) and the source, provide a link to the Creative Commons license and indicate if changes were made.

The images or other third party material in this chapter are included in the chapter's Creative Commons license, unless indicated otherwise in a credit line to the material. If material is not included in the chapter's Creative Commons license and your intended use is not permitted by statutory regulation or exceeds the permitted use, you will need to obtain permission directly from the copyright holder. 